\title{
PEMANFAATAN E-COMMERCE SEBAGAI MEDIA STARTUP BISNIS PADA ANAK-ANAK PANTI ASUHAN RIYADLUL JANNAH DAN PANTI ASUHAN AL MUSTAGHFIRIN SEMARANG
}

\author{
Diana Aqmala ${ }^{1}$, Amron ${ }^{2}$, Febrianur Ibnu Fitroh Sukono Putra ${ }^{3}$, dan Almira Santi Samasta ${ }^{4}$ \\ ${ }^{1,2,3,4}$ Fakultas Ekonomi dan Bisnis/Manajemen, Universitas Dian Nuswantoro \\ E-mail: ${ }^{1}$ diana.aqmala@gmail.com, ${ }^{2}$ amron@dsn.ac.id, ${ }^{3}$ fbr10@dsn.ac.id, \\ 4almirasanti@dsn.ac.id
}

\begin{abstract}
Abstrak
Permasalahan yang dihadapi oleh pengelola Panti Asuhan Riyadlul Jannah dan Panti Asuhan Al Mustaghfirin Semarang terkait dengan kelangsungan hidup anak-anak asuh baik yang masih sekolah maupun yang akan lulus dari tingkat SMA antara lain ketidakmampuan pengelola panti asuhan dalam pembiayaan kelanjutan dari studi anak-anak asuh setelah lulus dan kurangnya keterampilan anak-anak asuh dibidang multimedia menangkap peluang usaha di industri digital. Solusi yang ditawarkan dalam pengabdian kepada masyarakat ini adalah pendidikan secara komprehensif tentang perolehan pendapatan melalui wirausaha secara digital (e-commerce) dan pelatihan serta pendampingan pembuatan akun serta lapak di e-commerce, penentuan produk dan harga, promosi, pengemasan, hingga pendistribusian produk melalui jasa ekspedisi. Target luaran yang ingin dicapai adalah peningkatan kemampuan dan kreativitas dalam berwirausaha secara digital (e-commerce). Metode pengabdian kepada masyarakat ini adalah IbM (IPTEKS bagi Masyarakat) yang dilakukan melalui pendidikan dan arahan secara komunikasi dua arah (duplex), dilanjutkan dengan pelatihan keterampilan dan pendampingan penggunaan $e$ commerce, hingga simulasi pelaksanaan bisnis secara digital. Hasil yang diperoleh adalah dalam proses peningkatan keterampilan wirausaha melalui pemanfaatan e-commerce sebagai media startup bisnis dilakukan dengan tahapan: (1) Metode IbM, yaitu pelatihan pendaftaran dan pengelolaan profil e-commerce; (2) Mengelola akun e-commerce secara berkala hingga terjadi penjualan; (3) Menjual dan membuat pelaporan bisnis online yang telah dijalankan.
\end{abstract}

Kata kunci: e-commerce, IbM, panti asuhan, wirausaha.

\begin{abstract}
The problems faced by the managers of the Riyadlul Jannah Orphanage and the Al Mustaghfirin Orphanage Semarang are related to the survival of foster children who are still in school. Those who will graduate from high school level, including the inability of the orphanage manager to finance the continuation of the study of orphanages after graduation and the lack of skills of foster children in the multimedia sector seizes business opportunities in the digital industry. The solutions offered in this community service are comprehensive education on income generation through digital entrepreneurship (e-commerce) and training and assistance in creating accounts and stalls in e-commerce, determining products and prices, promotions, packaging, and product distribution through courier services. The output target to be achieved is increased ability and creativity in entrepreneurship digitally (e-commerce). This method of community service is IbM (Science and Technology for the Community) which is carried out through education and direction in two-way communication (duplex), followed by skills training and mentoring in the use of e-commerce, to simulating digital business implementation. The results obtained are in the process of improving entrepreneurial skills through the use of ecommerce
\end{abstract}

Keywords: e-commerce, IbM, orphanages, entrepreneurship. 


\section{PENDAHULUAN}

Menurut UNICEF, terdapat 4,4 juta yatim piatu di Indonesia. Terdapat sekitar 7.000 rumah panti asuhan dengan sekitar 500.000 yatim piatu. Hanya $6 \%$ dari 500.000 anak asuhan yatim piatu tersebut yang merupakan benar-benar anak yatim. Menurut hasil penelitian Save theChildren (UNICEF, 2009) 94\% dari anak asuhan yatim piatu di Indonesia "menjadi" yatim piatu karena alasan kemiskinan. Orang tua mereka tidak mampu untuk menafkahi mereka dengan layak, sehingga mereka "menitipkan" anak-anak mereka di rumah-rumah pengasuhan yatim piatu. Berdasarkan data BPS (2010) jumlah penduduk miskin di Indoneisa Maret 2010 mencapai 31,02 juta (13,33 persen dari total penduduk) (Kusuma \& Sugandi, 2019). Media sosial yang paling terkenal dan masih bertahan hingga saat ini adalah Facebook yang sudah melekat di benak masyarakat Indonesia. Seluruh masyarakat Indonesia yang mengikuti perkembangan zaman pasti memiliki account Facebook. Pada awal kemunculannya e-commerce memberikan dampak sangat signifikan pada fungsi penggunaannya sebagai media bisnis online (Muhartia \& Rinawati, 2017). Hingga saat ini transaksi yang dilakukan menggunakan media $e$ commerce masih berdasarkan asas kepercayaan karena belum adanya sistem yang mengatur keamanan dalam bertransaksi (Wibowo, 2016).

Pendidikan merupakan salah satu cara utama untuk menarik anak-anak yatim dan anakanak rentan di Indonesia keluardari perangkap kemiskinan (Sugiyarto, 2013). Sayangnya, tidak sedikit dari mereka yang menganggap pendidikan sebagai sesuatu yang "tidak terjangkau" dan "sia-sia". Ini disebabkan oleh dua hal antara lain pendidikan masih dipandang sebagai barang "mahal" sekalipun pemerintah pusat dan daerah telah memberikan pendidikan gratis terutama di sekolah-sekolah pemerintah, tetapi anak-anak yatim dan rentan tersebut tetap tidak mampu membeli seragam sekolah, sepatu, buku, dan perlengkapan sekolah lainnya. Selain itu bantuan pemerintah untuk penyelenggaraan panti asuhan masih terbatas sehingga penyelenggaraan panti asuhan sangat bergantung padas pronsorship dari pihak donatur. Sebab kedua, pelajaran formal di sekolah dianggap tidak memberi bekal dan ketreampilan memadai terutama untuk bisa mandiri secara ekonomi. Padahal bagi anak-anak yatim dan rentan ketrampilan tersebut sangat mereka perlukan. Pesatnya perkembangan teknologi khususnya e-commerce memberikan dampak pada perubahan perilaku para wirausaha dalam berbisnis, hal tersebut dikarenakan prosesnya menjadi lebih mudah dan meminimalisir biaya operasional yang keluar (Aqmala et al., 2020). Maka sudah semestinya e-commerce menjadi salah satu alternatif anak-anak panti asuhan untuk melatih keterampilan, meningkatkan kreativitas, serta mandiri dalam ekonomi. Namun, hal ini kurang mampu dibaca oleh anak-anak panti asuhan dikarenakan keterbatasan pengetahuan, sehingga kesulitan dalam memulai usahanya.

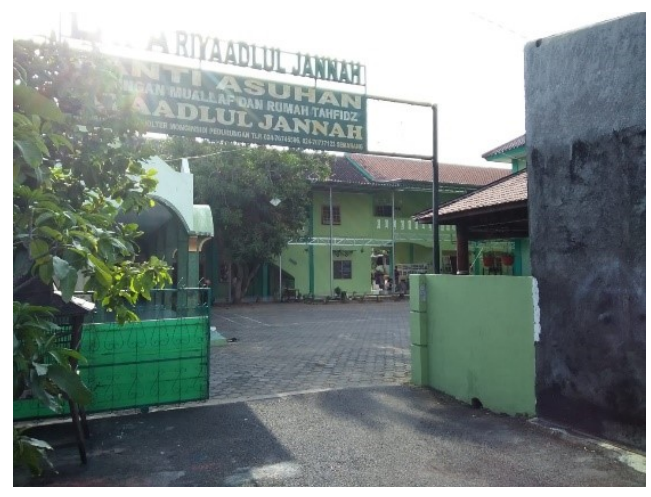

Gambar 1. Halaman Depan Panti Asuhan Riyadlul Jannah

Panti Asuhan "Riyaadlul Jannah" merupakan salah satu panti asuhan di Semarang. Dari awal berdiri, panti asuhan ini sudah mengharapkan terbangunnya rumah yang produktif dan tidak hanya untuk menampung anak-anak yatim dan dhuafa saja, namun dapat pula digunakan sebagai tempat serba bisa seperti pembimbingan terhadap muallaf ataupun pengembangan keterampilan anak-anak asuh seperti berwirausaha. Pengurus panti asuhan adalah Rofiq Hasyim 
Asyari. Bangunan panti yang besar merupakan sebuah gagasan tepat untuk tercapainya panti asuhan yang modern bagi anak-anak, sehingga mereka tidak lagi sedih karena kondisinya yang kurang beruntung. Namun, panti asuhan adalah sarana yang tepat bagi anak-anak asuh untuk bangkit dan menumbuhkembangkan potensi yang dimiliki.

Kebutuhan panti hingga saat ini masih diperoleh dari donator tetap dan beberapa usaha yang dirintis oleh pengurus. Hal ini merupakan suatu potensi yang sangat baik kedepannya, karena panti asuhan yang didukung dengan kreativitas anak-anak milenial secara bersama mengusahakan kemandirian ekonomi dan tidak bergantung pada para donator lagi. Dengan terfasilitasinya anak-anak panti asuhan menggunakan komputer dan internet akan membuat mereka semakin mudah dalam mengembangkan kreativitas dan keterampilannya berwirausaha. Panti asuhanpun dapat bekerja sama dengan anak-anak asuh untuk mengembangkan usaha melalui bisnis secara digital.

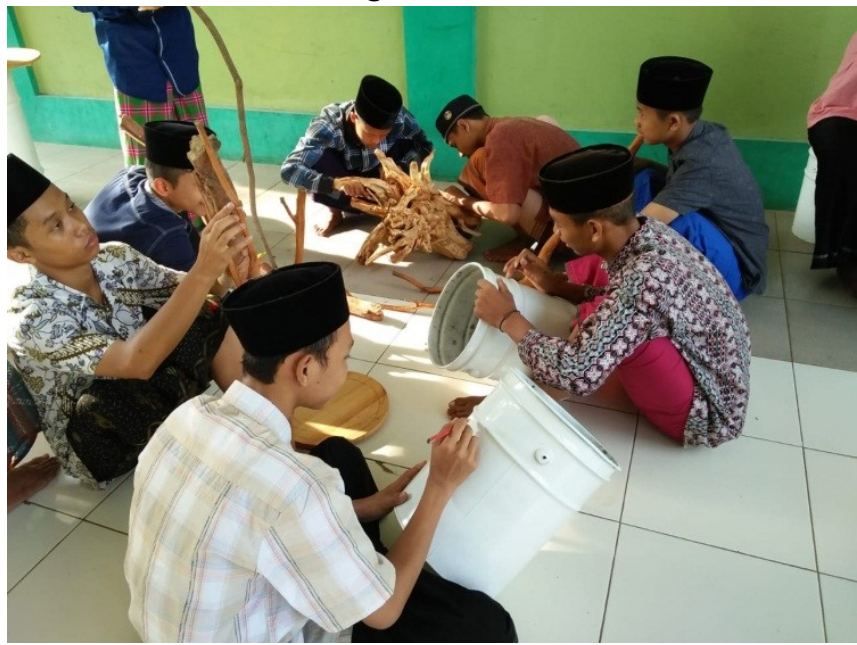

Gambar 2. Pembuatan kerajinan tangan dari akar

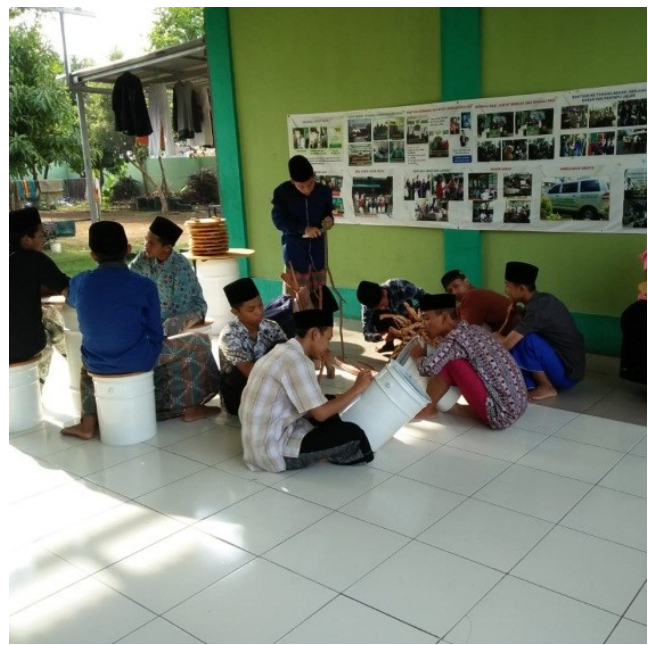

Gambar 3. Pembuatan meja dari tong

Pemanfaatan fasilitas teknologi yang tersedia secara kurang komprehensif akan membuat kreativitas dan keterampilan anak-anak asuh terhambat, sehingga nantinya berdampak pada ketidakmampuan beradaptasi didunia bisnis yang serba digital. Semakin jauh, anak-anak panti asuhan bisa saja menjadi tidak mampu mandiri secara ekonomi bahkan setelah tamat sekolah. Panti Asuhan Al Mustaghfirin juga merupakan salah satu panti asuhan di Semarang yang memiliki sistem manajemen yang baik. Prosedur pengasuhan anak-anak dijalankan dengan baik oleh pengurus sesuai dengan peraturan yang dibuat pemerintah. Pengurus panti asuhan sangat memperhatikan pendidikan bagi anak-anak panti tersebut. Terbukti dengan adanya beberapa anak yang sudah memasuki jenjang pendidikan tinggi, yaitu 2 dari 35 anak asuh. Pengurus panti juga mengajarkan anak-anak untuk belajar menghadapi perkembangan dunia usaha dengan mengarahkan untuk memulai berbisnis dan berjualan dengan modal kecil. Hal tersebut dianggap oleh pengasuh dapat melatih karakter anak. Pengurus panti asuhan Al-Mustaghfirin adalah $\mathrm{H}$. Ghufron Noor, S.Pd.I.

Anak-anak asuh dipanti asuhan ini memiliki keterampilan dan kreativitas yang baik dalam membuat sebuah karya, namun karena keterbatasan dalam program pembelajaran yang mengarah kepada kemandirian ekonomi dan kewirausahaan, sehingga anak-anak asuh kurang mampu membaca potensi diri dan wadah untuk menyalurkannya. Dunia bisnis yang serba digital akan memacu anak-anak asuh untuk bekerja keras agar mampu beradaptasi, sehingga mereka memerlukan wadah agar dapat menghasilkan pendapatan sendiri baik selama sekolah maupun setelah tamat sekolah. 

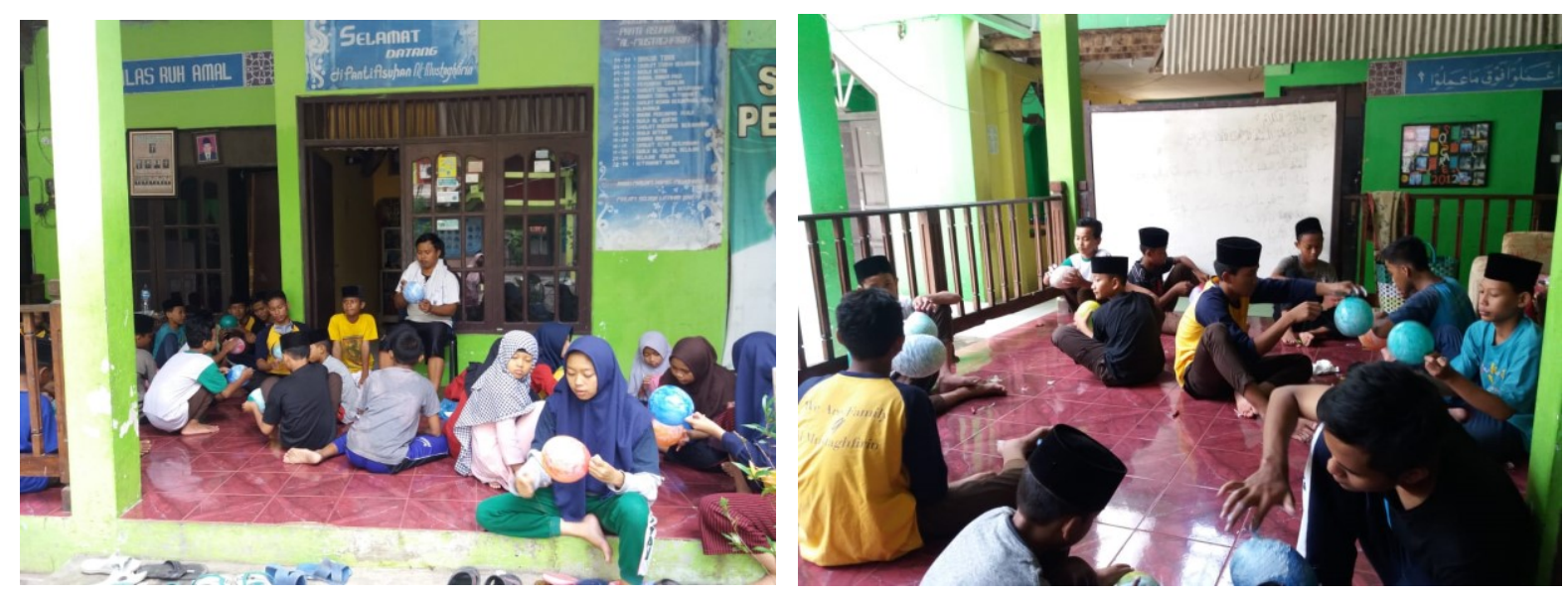

Gambar 4. Kegiatan pembuatan lampu lampion

Maka dari itu, alternatif kegiatan seperti pendidikan, pelatiha, dan pendampingan berwirausaha harapannya dapat memberikan manfaat dalam meningkatkan kemampuan dan keterampilan anak-anak panti asuhan tersebut dalam menjalankan bisnis secara digital. Adanya motivasi kuat untuk memiliki kemandirian secara ekonomi membuat anak-anak panti asuhan merasa bahwa menjadi anak panti asuhan bukanlah halangan untuk terus berkembang khususnya menjadi wirausaha.

Persaingan dunia usaha dapat dimulai saat masih menempuh masa pendidikan bahkan setelah lulus, hal tersebut dapat menjadi momok bagi siswa maupun khususnya anak-anak panti asuhan. Banyak orang yang berlomba-lomba untuk menciptakan usaha baru dan melalukan segalanya untuk dapat bertahan dalam persaingan. Anak-anak yatim dan tidak mampu yang bernaung di panti asuhan harus memiliki karakter dan motivasi yang kuat untuk mempersiapkan diri memulai usaha secara digital guna menghadapi persaingan di industri online. Oleh karena itu perlu adanya pendidikan, pelatihan, dan pendampingan kepada anak-anak panti asuhan terkait pengetahuan berwirausaha dan kemampuan manajerial lainnya seperti pemasaran, pengemasan, pencarian supplier, pencatatan laporan keuangan, hingga pengelolaan lapak di marketplace. Hal tersebut diperlukan sebagai bekal sekaligus meningkatkan kepercayaan diri pada anak panti asuhan dalam memulai dan menjalani bisnis secara digital. Maka dari itu solusi yang ditawarkan untuk menyelesaikan permasalahan mitra adalah:

a. Pendidikan secara komprehensif tentang perolehan pendapatan melalui wirausaha secara digital (e-commerce)

Peningkatan keterampilan anak asuh yang masih ataupun telah lulus dari bangku SMA dilakukan melalui pendidikan secara komprehensif tentang berwirausaha secara kreatif dan sesuai dengan industri digital. Berdasarkan hasil identifikasi di lapangan yang melibatkan mitra secara langsung telah ditemukan permasalahan dalam hal keterampilan anak asuh dalam penguasaan perangkat lunak yang digunakan dalam mengelola bisnis secara digital (online). Terdapat keterampilan dasar yang dipersyaratkan dalam bisnis online yakni pengaplikasian aplikasi dan anak-anak asuh telah memilikinya, sehingga cukup dikembangkan keterampilannya saja dalam pengoperasian bisnis online melalui marketplace.

b. Pelatihan dan pendampingan pemanfaatan e-commerce sebagai alternatif sarana bisnis digital yang efektif

Gambaran ipteks yang akan diperoleh mitra pengabdian masyarakat antara lain strategi pemasaran yang dilakukan dengan memanfaatkan sosial media agar meminimalisir biaya, pencatatan keuangan dengan menggunakan gadget, dan pengelolaan bisnis yang efektif menggunakan sistem digital yang tanpa harus memproduksi sendiri ataupun memiliki gudang untuk persediaan. Pelatihan dan pendampingan marketplace yang diinginkan, selanjutnya menentukan produk dan harga yang akan ditawarkan, strategi pemasaran yang digunakan, pengemasan produk sesuai standar, pendistribusian produk melalui jasa ekspedisi, hingga membangun customer relationship management dengan konsumennya. Ecommerce merupakan salah satu unsur penting yang menunjang perekonomian diberbagai 
khalayak masyarakat. Bentuk pembaharuan dibisnis ini adalah dengan munculnya mall secara online yang disebut marketplace. Didalam marketplace terdapat ketersediaan informasi yang lengkap mulai dari profil pengusaha, produk/jasa yang ditawarkan, harga, lokasi usaha, serta cara transaksinya. Maka dari itu, pemanfaatan e-commerce akan membantu anak-anak panti memperoleh pendapatan sendiri dan menumbuhkan kemandirian, sehingga tidak perlu bingung ataupun bergantung pada panti asuhan lagi apabila telah lulus sekolah.

\section{METODE}

Metode pendekatan pada pelaksanaan kegiatan pengabdian masyarakat ini yaitu mengidentifikasi permasalahan mitra melalui metode in depth interview. Pelaksanaan kegiatan pengabdian masyarakat pada bagian pendidikan berwirausaha dilakukan melalui seminar dan diskusi bersama Panti Asuhan Riyadlul Jannah dan Panti Asuhan Al Mustaghfirin. Kegiatan tersebut dilakukan melalui penyampaian materi dan dilanjutkan sesi diskusi mengenai kewirausahaan yang diaplikasikan ke dalam bisnis online. Pelatihan dan pendampingan pemanfaatan e-commerce sebagai alternatif sarana bisnis digital yang efektif akan dilaksanakan di laboratorium komputer masing-masing panti asuhan. Kegiatan ini dilaksanakan oleh tim pengusul yang memiliki keahlian di bidang pemasaran, produksi, kewirausahaan, dan $e$ commerce. Pelatihan dan pendampingan berwirausaha secara digital dibantu dengan alat berupa laptop, kamera, dan mikrofon agar pelaksanannya lebih efektif. Metode dalam menyelesaikan permasalahan bidang manajemen bisnis dilakukan melalui tahapan yang dapat dilihat pada gambar berikut:

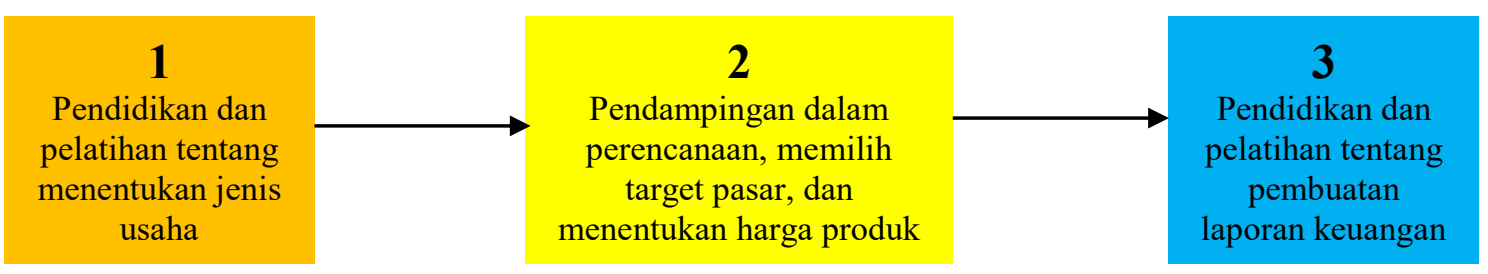

Gambar 5. Metode Penyelesaian Permasalahan Manajemen Bisnis

Sedangkan metode yang diterapkan untuk proses penyelesaian masalah produksi dilakukan melalui beberapa tahapan yang dapat dilihat pada gambar berikut:

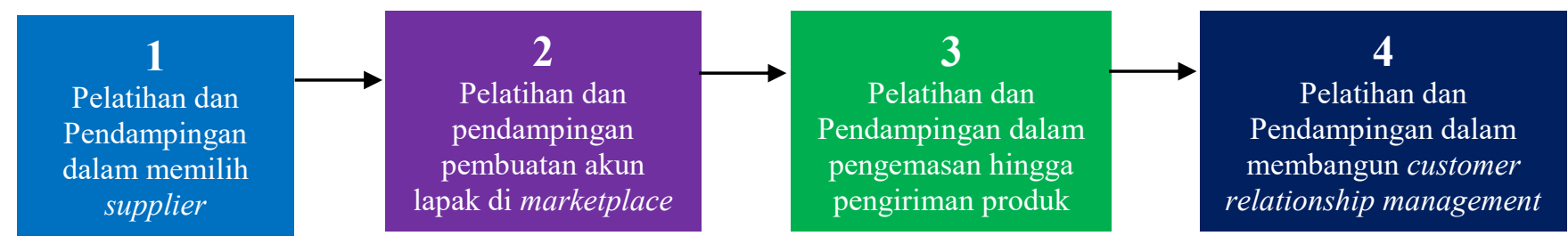

Bentuk nyata partisipasi mitra adalah dengan memberikan masukan terhadap permasalahan nyata yang sedang terjadi melalui pelaksanakan Focus Group Discussion (FGD) dengan tim pengabdian masyarakat dan secara kooperatif mengikuti pendidikan, pelatihan, dan pendampingan yang dilaksanakan, sehingga memperoleh hasil yang jelas dan dapat dievaluasi. Sedangkan proses evaluasi dilakukan melalui beberapa tahapan, antara lain:

2.1 Mengevaluasi pemahaman anak-anak asuh tentang berwirausaha secara digital melalui angket yang diberikan oleh tim pelaksana kegiatan pengabdian.

2.2 Mengevaluasi peningkatan keterampilan anak-anak asuh dalam pengaplikasian gadget dengan simulasi tugas pembuatan pencatatan transaksi penjualan dan laporan keuangan.

2.3 Mengevaluasi kreativitas anak-anak asuh dalam menentukan target pasar, produk yang akan dijual beserta harga yang akan ditawarkan melalui presentasi yang dijadwalkan. 
2.4 Mengevaluasi efektivitas pengelolaan lapak online yang dimiliki anak-anak asuh dilakukan melalui simulasi pengaplikasian marketplace dan melakukan pelaporan kemajuan usaha.

Keberlanjutan program kemitraan masyarakat ini setelah selesai antara lain menyediakan jasa konsultasi bagi anak-anak asuh yang belum ataupun telah memiliki lapak online hingga seluruh anak asuh mampu mandiri secara ekonomi. Selain itu program ini ememproyeksikan anak-anak asuh yang telah memiliki dan mengoperasikan lapak online secara mandiri untuk memiliki manajemen bisnis dengan skala yang lebih besar mulai dari lini produk, sistem operasional, hingga membuka lapangan pekerjaan.

\section{HASIL DAN PEMBAHASAN}

Rendahnya wawasan anak-anak panti asuhan tentang kebermanfaatan teknologi digital sebagai media berwirausaha menjadi sebuah kendala utama dalam mempersiapkan kemandirian secara ekonomi dimasa mendatang. Keterbatasan kemampuan beradaptasi dengan pemanfaatan e-commerce yang syarat akan kecanggihan teknologi, sehingga anak-anak panti asuhan memerlukan program yang secara komprehensif dapat membimbing dan mengarahkan mereka agar dapat secara mandiri mengelola bisnis online yang dimiliki. E-commerce merupakan salah satu unsur penting yang menunjang perekonomian diberbagai khalayak masyarakat. Bentuk pembaharuan dibisnis ini adalah dengan munculnya mall secara online yang disebut marketplace. Didalam marketplace terdapat ketersediaan informasi yang lengkap mulai dari profil pengusaha, produk/jasa yang ditawarkan, harga, lokasi usaha, serta cara transaksinya. Maka dari itu, pemanfaatan e-commerce akan membantu anak-anak panti memperoleh pendapatan sendiri dan menumbuhkan kemandirian, sehingga tidak perlu bingung ataupun bergantung pada panti asuhan lagi apabila telah lulus sekolah.

Kegiatan awal yang dilakukan untuk dapat memperoleh informasi terkait kendala dan kebutuhan solusi yang dibutuhkan anak-anak panti asuhan agar dapat menjalankan bisnis secara online melalui FGD dan sharing session dengan topik kemandirian ekonomi dan kewirausahaan. Kegiatan FGD dan sharing session ini dilaksanakan pada hari Ahad, 25 Oktober 2020. Kegiatan tersebut dilaksanakan di Panti Asuhan Riyaadlul Jannah dengan peserta kurang lebih sebanyak 15 orang dan 7 orang di Panti Asuhan Al-Mustaghfirin. Keseluruhan tahapan pelaksanaan yang dijalankan tim pengabdi dalam mengatasi permasalahan mitra dapat berjalan efektif. Hal ini disebabkan tidak saja karena program-program yang telah dirancang oleh tim pengabdi memang merupakan program-program yang dibutuhkan, tetapi juga karena adanya dukungan dari pihak-pihak pengurus Panti Asuhan Riyaadlul Jannah dan Panti Asuhan AlMustaghfirin yang merupakan mitra dalam program ini.
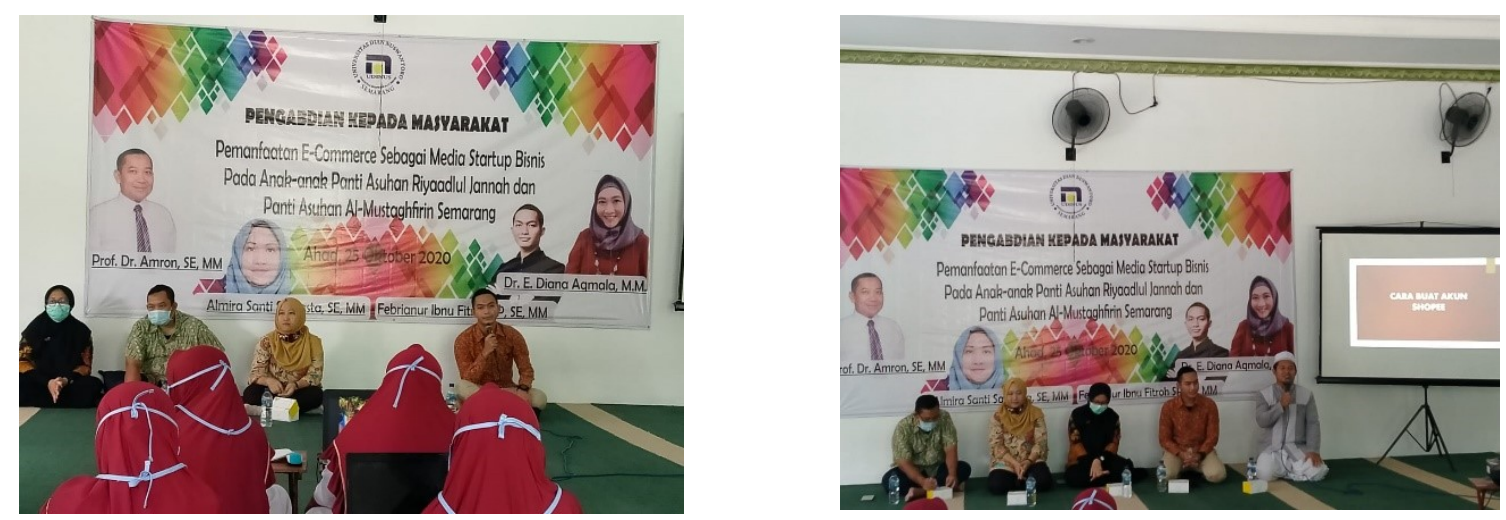

Gambar 6. Kegiatan Pendampingan Kepada Mitra Panti Asuhan Riyaadlul Jannah 

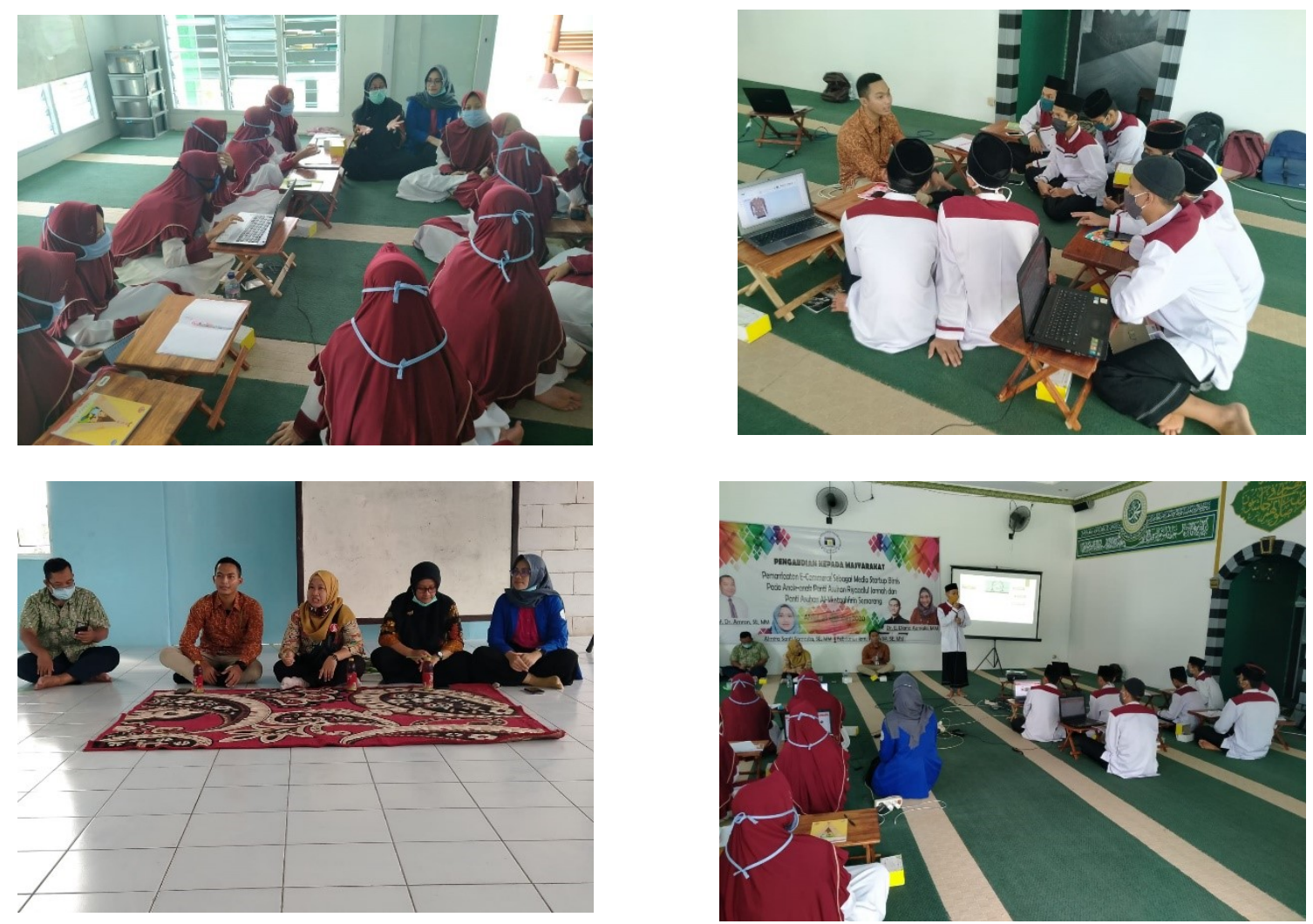

Gambar 7. Kegiatan Pendampingan Kepada Mitra Panti Asuhan Al-Mustaghfirin

Hasil dari rancangan program dari tim, maka dihasilkan tiga tahapan kegiatan, antara lain tahapan investigasi, tahapan persiapan kegiatan, dan tahapan implementasi.

\section{Tahapan Investigasi}

Tahapan investigasi dalam program ini dimaksudkan untuk menggali komponen-komponen permasalahan yang tengah dihadapi mitra, mendengarkan berbagai keluhan mitra dalam meningkatkan pemahaman serta kemampuan praktik berbisnis secara online, dan harapan mitra terhadap meningkatnya kemandirian ekonomi semenjak masih dibangku sekolah. Dalam melakukan tahapan investigasi diketahui bahwa selama ini yang dilakukan oleh anak-anak Panti Asuhan Riyaadlul Jannah adalah terbatas hingga belanja online saja. Pengurus Panti Asuhan Riyaadlul Jannah dan Panti Asuhan Al-Mustaghfirin telah berinisiatif untuk mulai membatasi anak-anak untuk terus menerus belanja online dengan tujuan agar tidak terlalu konsumtif. Dalam kegiatan investigasi juga diketahui bahwa produk-produk belanja online yang dibeli oleh anak-anak panti asuhan antara lain kebutuhan sehari-hari, pakaian, sepatu, tas, dan lain sebagainya. Selain itu, pada tahapan investigasi ini terungkap bahwa realitas yang tengah dihadapi untuk mencukupi kebutuhan hidup anak-anak panti asuhan yang bernaung di Panti Asuhan Riyaadlul Jannah dan Panti Asuhan Al-Mustaghfirin saat ini masih sangat bergantung pada bantuan dari donatur saja. Hal inilah yang mendorong pimpinan Panti Asuhan Riyaadlul Jannah dan Panti Asuhan Al-Mustaghfirin memiliki keinginan bahwa anak-anak harus memiliki kemandirian secara ekonomi sejak muda melalui cara berwirausaha dengan memanfaatkan ecommerce yang terintegrasi internet dengan kecanggihan teknologi dan modal yang relatif terjangkau.

Tahapan investigasi yang dilakukan oleh tim pengabdi juga bertujuan untuk mengetahui program-program apa saja yang dibutuhkan dan menjadi skala prioritas dan belum pernah tersentuh di Panti Asuhan Riyaadlul Jannah dan Panti Asuhan Al-Mustaghfirin. Bekal ilmu pengetahuan, dan peningkatan keterampilan berwirausaha secara online sangat dibutuhkan guna menunjang terwujudnya anak-anak Panti Asuhan Riyaadlul Jannah dan Panti Asuhan Al- 
Mustaghfirin yang sejahtera dan mandiri. Rangkain program kami hadir untuk menjembatani kepentingan anak-anak Panti Asuhan Riyaadlul Jannah dan Panti Asuhan Al-Mustaghfirin agar mampu meningkatkan kesejahteraan dan kemandirian secara ekonomi. Diharapkan pada masa yang akan datang melalui kegiatan ini dapat menghasilkan outcome sesuai yang diharapkan bagi peningkatan taraf hidup masyarakat tidak hanya di Panti Asuhan Riyaadlul Jannah dan Panti Asuhan Al-Mustaghfirin akan tetapi juga untuk masyarakat luas.

\section{Tahapan Persiapan Kegiatan}

Pada tahap ini tim pelaksana pengabdian kepada masyarakat merencanakan materi dan topik bahasan yang akan didiskusikan pada saat pelaksanaan. Selain itu tim pelaksana juga merencanakan jadwal pelaksanaan kegiatan, survei lokasi mitra pengabdian dan berkoordinasi dengan mitra pengabdian terkait fasilitas pendukung yang dibutuhkan saat pelaksanaan kegiatan.

\section{Tahapan Implementasi}

Pendekatan FGD dan sharing session digunakan dalam kegiatan pengabdian agar mitra dapat berpartisipasi aktif terhadap seluruh kegiatan yang dilaksanakan. FGD dalam kegiatan ini diselenggarakan sebanyak satu kali. FGD difungsikan juga sebagai sarana sharing pengalaman dengan cara memberikan kesempatan kepada mitra untuk saling berbagi pengalaman, gagasan, ide, dan harapan dimasa mendatang sebagai wirausaha. Selanjutnya mitra di Panti Asuhan Riyaadlul Jannah dan Panti Asuhan Al-Mustaghfirin diberi pendampingan tentang pemanfaatan salah satu marketplace (Shopee) untuk membuat profil usaha dan upload produk yang dijual. Setelah mitra menyelesaikan pendampingan yang dilakukan, mereka mempresentasikan bisnis online yang dimiliki agar dapat diberi masukan, sehingga kedepannya agar mampu menjalankan bisnisnya secara mandiri dan memperoleh penjualan yang konsisten.

\section{KESIMPULAN DAN SARAN}

Kesimpulan yang dapat diperoleh dari pelaksanaan program kemitraan masyarakat ini antara lain kegiatan FGD dan sharing session tentang program pemanfaatan e-commerce sebagai media startup bisnis anak-anak Panti Asuhan Riyaadlul Jannah dan Panti Asuhan AlMustaghfirin untuk meningkatkan kemandirian ekonomi serta kesejahteraan dengan secepat mungkin. Anak-anak Panti Asuhan Riyaadlul Jannah dan Panti Asuhan Al-Mustaghfirin mampu meningkatkan kreativitas dan inovasi yang dimiliki pada dirinya sehingga dapat mengelola bisnis online secara baik dan komprehensif. Anak-anak Panti Asuhan Riyaadlul Jannah dan AlMustaghfirin dapat mengelola bisnis online dengan memiliki cakupan pasar yang lebih luas dengan kebutuhan biaya yang relatif rendah untuk menghadapi perkembangan dunia usaha didalam industri yang sangat pesat.

Berdasarkan hasil pelaksanaan program kemitraan masyarakat, kami menyarankan agar Pimpinan Universitas Dian Nuswantoro terus mendorong terlaksananya program kemitraan masyarakat termasuk dalam bidang pemberdayaan bidang kemandirian ekonomi yang dikoordinir oleh Lembaga Penelitian dan Pengabdian pada Masyarakat (LPPM). Selain itu Pimpinan Universitas Dian Nuswantoro juga meningkatkan kerjasama diantara pihak-pihak terkait agar program ini dapat terlaksana secara berkelanjutan sehingga adik-adik panti asuhan menyadari akan pentingnya peran mereka dalam kemandirian ekonomi para generasi muda di masa depan melalui wirausaha dengan memanfaatkan kecanggihan teknologi secara efektif dan efisien.

\section{UCAPAN TERIMA KASIH}

Tim Pengabdian mengucapkan terima kasih kepada seluruh pihak yang terlibat termasuk Panti Asuhan Riyaadlul Jannah dan Panti Asuhan Al-Mustaghfirin, serta Lembaga Penelitian dan Pengabdian kepada Masyarakat Universitas Dian Nuswantoro melalui program pendaan internal yang telah memberi kesempatan dan dukungan kepada kami untuk melakukan kegiatan secara optimal. 


\section{DAFTAR PUSTAKA}

[1] Aqmala, D., Putra, F.I.F.S., Suseno, A. (2020). Faktor-faktor yang Membentuk Minat Berwirausaha Mahasiswa Program Studi Manajemen Universitas Dian Nuswantoro. Dayasaing: Jurnal Manajemen Sumber Daya, 22(1), 60-70.

[2] Handaru, A. W., Pagita, M. P. and Parimita, W. (2015) 'Karakteristik Entrepreneur Melalui Multiple Diskriminan Analisis', JRMSI - Jurnal Riset Manajemen Sains Indonesia, 6(1), p. 351. doi: 10.21009/jrmsi.006.1.02.

[3] Irmawati, D. (2011) 'Pemanfaatan E-Commerce Dalam Dunia Bisnis', Jurnal Orasi Bisnis, VI(November), pp. 95-112.

[4] Kusuma, D. F., \& Sugandi, M. S. (2019). Strategi Pemanfaatan Instagram Sebagai Media Komunikasi Pemasaran Digital Yang Dilakukan Oleh Dino Donuts. Jurnal Manajemen Komunikasi, 3(1), 18. https://doi.org/10.24198/jmk.v3i1.12963

[5] Lesmana, I. G. N. A. (2012) 'Analisis Pengaruh Media Sosial Twitter terhadap Pembentukan Brand Attachment ( Studi : PT . XL AXIATA )’, p. 134.

[6] Muhartia, I. R. and Rinawati, R. (2017) 'Instagram as Media For Marketing Commucation Grow Up Grow Up', in Prosiding Manajemen Komunikasi, pp. 59-65.

[7] Sugiyarto, E. C. (2013) "Gerakan Kewirausahaan Nasional Untuk Menyebar Virus Wirausaha'." Tersedia pada: http://www.setkab.go.id/artikel-7434.html. (Diakses pada 9 April 2020)

[8] Wibowo, E. A. (2016). Pemanfaatan Teknologi E-Commerce Dalam Proses Bisnis. Jurnal Equilibiria, 1(1), 95-108. http://journal.unrika.ac.id/index.php/equi/article/view/222 